\title{
Upaya Pemuda Kristen dalam Menjalankan Peribadatan di Gereja Desa pada masa Pandemi Covid-19
}

\author{
Wardi \\ Sekolah Tinggi Teologi Sangkakala \\ Wardi050693@gmail.com
}

\begin{abstract}
Abstrak
Pandemi covid-19 yang masih merebak hingga saat ini telah menutup ibadahibadah langsung dalam gereja. Bukan hanya gereja yang terletak di perkotaan, namun gereja yang berada di desa-desa juga tidak luput dari masalah pandemi Covid-19. Demikian juga persekutuan anak muda Kristen yang ada pun ikut diliburkan sementara aktivitasnya. Tujuan penelitian ini adalah untuk mengeksplorasi upaya yang dapat dilakukan oleh pemuda Kristen, khususnya di gereja desa dalam menghadapi pandemi Covid-19. Metode penelitian yang digunakan adalah kualitatif deskriptif untuk mengungkapkan upaya yang dapat dilakukan oleh pemuda Kristen dalam menghadapi tantangan pandemi covid-19. Hasil penelitian menunjukkan bahwa pemuda Kristen menjadi tonggak utama dalam menjalankan peribadatan di gereja lokal, terkhusus desa, karena perubahan yang signifikan. Karena itu, perlu dengan cepat melakukan adaptasi untuk dapat menemukan strategi yang tepat dalam menjalankan ibadah di gereja desa.
\end{abstract}

Kata Kunci: pandemi; Gereja; pemuda Kristen; persekutuan; adaptasi

\begin{abstract}
The COVID-19 pandemic that is still spreading to this day has closed direct services in the church. Not only churches located in urban areas, but churches located in villages are also not spared the problem of the Covid-19 pandemic. Likewise, the existing Christian youth associations were also temporarily closed for their activities. The purpose of this research is to explore the efforts that can be made by Christian youth, especially in village churches in the face of the Covid-19 pandemic. The research method used is descriptive qualitative to reveal the efforts that can be made by Christian youth in facing the challenges of the covid-19 pandemic. The results showed that Christian youth became the main milestone in carrying out worship in local churches, especially villages, because of significant changes. Therefore, it is necessary to adapt quickly to be able to find the right strategy in carrying out worship at the village church.
\end{abstract}

Keywords: pandemic; Church; Christian youth; fellowship; adaptation 


\section{PENDAHULUAN}

Pandemi covid-19 yang melanda di Indonesia saat ini telah mengakibatkan perubahan yang drastis dalam berbagai bidak. Sebut saja ekonomi, pendidikan, pekerjaan, bahkan peribadatan. Pandemi ini seakan menjadi tonggak memasuki era disrupsi sesungguhnya (Kasali, 2017). Dalam kehidupan keagamaan, hampir seluruh tempat ibadah telah dibatasi kehadiran dan intensitas kegiatannya. Kebijakan ini diambil oleh pemerintah dalam rangka memutus penyebaran virus ini.

Karenanya, pemerintah memberlakukan Pemberlakuan Pembatasan Kegiatan Masyarakat atau yang biasa dikenal dengan istilah PPKM. PPKM ini menimbulkan pengaruh yang besar terhadap kegiatan setiap manusia maupun dalam kegiatan peribadatan (Panjaitan et al., 2021).

Bagaikan bola salju, langka yang pemerintah lakukan juga tidak semata-mata berhasil. Sebab meskipun sisi kesehatan dapat dikontrol, tetapi sisi psikologi seseorang juga dapat terkena. Salah satu perasaan universal yang nyata adalah fakta bahwa manusia sangatlah rapuh (Kumowal \& Kalintabu, 2021:44) atau mengalami ketakutan dan kecemasan yang disebabkan tekanan mental selama pandemi ini (G. Pakpahan, 2020; G. K. R. Pakpahan, 2020).

Menghadapi persoalan diatas, gereja sebagai tubuh Kristus dan representatif kerajaan Allah di dunia ini dibawa kepada dimensi yang baru dalam menjaga domba yang Tuhan percayakan. Ibadah online pun menjadi solusi sementara yang dapat diambil guna tetap menjalankan fungsi pengembalaan dan gereja.

Persoalan muncul lagi akibat solusi ini, yaitu adaptasi dari jemaat, baik sekolah minggu, remaja, pemuda, dan orang tua dalam mengikuti ibadah ini tanpa kehilangan esensi dari ibadah. Sebab apabila jemaat dapat beradaptasi dengan tepat dan baik maka perkembangan persekutuan peribadatan saat ini tidak menjadi masalah, tetapi ketika tidak dapat mengikuti adaptasi dengan kondisi saat ini maka perkembangan jemaat akan terhambat (Suratman, 2021). Kemampuan beradaptasi ini menunjukkan sikap kepemimpinan yang dapat beradaptasi dalam 
DIEGESIS: Jurnal Teologi

Volume 6 No. 2, Agustus 2021.

keadaan yang berubah (Pantan, 2007).

Pemuda Kristen sebagai tulang punggung hendaknya tetap dapat kuat di tengah kondisi saat ini maupun tantangan zaman saat sekarang ini (Untung et al., 2021). Pemuda sebagai bagian dari lapisan masyarakat dan memainkan peran penting, dimana pemuda harus memberikan kontribusi nilai-nilai kemanusian dalam kehidupan berbangsa dan bernegara (Trisna, 2016). Apalagi di tengah situasi ini pandemi covid-19, peran pemuda yang dinamis yang penuh energi sagat diharapkan dapat menjadi tolak ukur perubahan untuk membantu pemerintah memutus mata rantai penyebaran Covid-19.

Masa remaja ini masa yang sangat penting, sangat kristis, dan sangat rentan jika manusia melewati masa remaja ini dengan kegagalan mereka akan kesusahan di masa selanjutnya (Pailang \& Palar, 2012). Peranan Gereja terhadap masa remaja ini sangat penting dalam menolong mereka menemukan jati diri mereka. Dengan adanya pandemi covid-19 ini banyak pemuda dalam pertumbuhan kerohanian bersama-sama mereka terhambat karena terbatasnya waktu untuk bertemu bersama untuk beribadah dan belajar firman Tuhan bersama-sama. Dalam persekutuan kaum muda Kristen ketika adanya PPKM yang ada ini banyak gereja yang meliburkan kegiatan persekutuan kepemudaan mereka. Ada yang hanya kirim bacaan firman Tuhan ke group kepemudaan, ada yang tidak ada kegiatan sama sekali, ada yang melakukan pertemuan lewat zoom maupun video call whatsapp (Benyamin et al., 2021).

Perilaku yang ditunjukan oleh anak muda ini pun cenderung berubah. Berubah karena kondisi saat ini yang sedang dialami. Kondisi pandemi covid-19 membuat perilaku kau manak muda terutama anak muda Kristen yang semakin menjauh dari keteladanan Yesus Kristus yang diajarkan di kegiatan kepemudaan di Gereja.

Sebagai orang yang beriman kepada Tuhan Yesus Kristus, maka peran pemuda Kristen untuk terus bertumbuh dan berkembang kerohanian di tengah pandemi saat ini merupakan hal yang sangat penting. Sebab pandemi covid-19 ini dapat berkaitan dengan perubahan pola manusia dalam berinteraksi dan 
bersosial untuk mewujudkan pertumbuhan rohaninya.

Kondisi saat ini yang begitu berat dirasakan oleh semua orang yaitu pandemi covid-19. Kondisi saat ini bukan hanya dialami oleh orangorang yang tua tetapi semua orang baik itu anak, remaja, dewasa, dan orang tua. Dalam gereja pun dirasa kondisi saat ini begitu susah untuk dilalui. Bukan hal yang susah untuk dilewati tetapi dalam hal melayani setiap orang karena terbatasnya jarak dan waktu untuk melayani setiap jemaat.

Dalam peribadatan anak muda pun mengalami hal yang sama yaitu terbatas jarak dan waktu untuk dapat berkumpul di gereja dalam persekutuan. Masalah ini tidak hanya dialami beberapa gereja tetapi hampir semua gereja mengalami hal yang sama. Maka penulis meneliti pemuda Kristen dalam menghadapi pandemi covid-19. Karena tulang punggung setiap gereja adalah anak muda itu sendiri.

Penelitian ini bertujuan untuk memberikan kajian deskriptif tindakan yang dapat dilakukan oleh pemuda Kristen dalam gereja desa dalam beradaptasi dengan baik untuk dapat melakukan persekutuanpersekutuan bersama di tengah Pandemi covid-19.

\section{METODE PENELIAN}

Metode penelitian yang
dipakai yaitu metode kualitatif mendeskripsikan hasil dari observasi lapangan dengan pendekatan kepustakaan (Chandra, 2019). Jadi penelitian kualitatif adalah jenis penelitian yang dilakukan tidak menggunakan prosedur statistis dan bertujuan untuk mengungkapkan gejala secara holistic-kontekstual dengan mengumpulkan data-data berupa referensi kepustakaan, dokumen-dokumen, dan sebagainya yang terkait dengan penelitian ini (Kumowal \& Kalintabu, 2021). Sumber langsung dari gagasan ini merupakan hasil dari observasi lapangan yang terdapat dalam sebuah kepemudaan yang ada di gerejagereja yang ada di desa. Selain itu juga penulis juga merujuk pada artikel-artikel jurnal maupun sumbersumber internet yang berhubungan dengan permasalahan yang ada ini sesuai dengan penelitian yang dibahas.

Dalam penelitian kualitatif ini yang telah dikemukakan merupakan 
penelitian yang masih bersifat sementara dan akan terus berkembang dalam situasi dan kondisi sosial tertentu (Sugiyono, 2016:291). Jadi penelitian ini sangat terbaru melihat kondisi saat ini yang sedang terjadi di dalam lingkungan kehidupan bergereja terkhusus kehidupan anak muda Kristen yang ada di desa. Penelitian ini dapat juga dikembangkan ketika kondisi dan keadaan yang sudah berubah kemudian hari.

\section{Langkah-langkah yang}

diambil untuk pengambilan data-data yang ada yaitu dengan terlebih dahulu melakukan observasi dan menganalisis dampak pandemi covid19 terhadap kegiatan peribadatan kaum muda Kristen yang ada. Kemudian melakukan perumusan terhadap data-data yang masih mentah dan melakukan literatur guna memperoleh gambaran permasalah yang sebenarnya.

\section{Selanjutnya memaparkan}

hasil kajian dan perumusan dalam bentuk karya ilmiah. Setelah menemukan kelebihan dan kekurangan yang ada dalam penelitian ini maka penulis dapat memberikan usulan bagaimana seharusnya dan sebaiknya adaptasi dalam keadaan saat ini bagi kaum muda Kristen agar dapat bertindak demi kelangsungan ibadah pemuda dengan baik dan tepat sesuai dengan kondisi saat ini.

\section{HASIL DAN PEMBAHASAN}

\section{Kebijakan Pemerintah dalam} menghadapi Pandemi Covid-19

Pandemi covid-19 yang terjadi di bangsa Indonesia yang semakin hari-semakin bertambah angka pasien yang terkena virus covid-19 dan adanya varian yang baru masuk ke Indonesia membuat pemerintah pusat mengeluarkan kebijakan tentang adanya pemberlakuan pembatasan kegiatan masyarakat. Pemberlakuan ini diberlakukan hampir di semua wilayah yang berada di Indonesia. Dampak yang terasa dari kegiatan ini yaitu dipulau Jawa dan Bali karena angka kenaikan penularan yang terkena covid1-19 ini semakin tinggi yang terletak didaerah Jawa dan Bali. Atas dasar ini akibat angka penularan covid-19 yang semakin hari semakin tinggi membuat pemerintah melakukan kebijakan yang harus segera dilakukan untuk menekan angka penularan ini. 
Kebijakan yang ada terkait pemberlakuan pembatasan kegiatan masyarakat ini merupakan suatu yang tidak dapat dihindari karena ini berguna untuk menekan laju penularan covid-19, serta dapat mengendalikan kapasitas rumah sakit yang menangani pasien covid-19 agar tidak memenuhi kapasitas penampungan di rumah sakit (Susiwijono Moegiarso, 2021).

Awal dimulainya kegiatan ini yaitu berawal dari tanggal 3 Juli 2021 yang direncanakan hanya sampai tanggal 20 Juli 2021. Dengan adanya kebijakan ini menunjukan angka penurunan yang signifikan namun untuk lebih memberikan dampak penurunan kasus yang panjang maka pemerintah memutuskan untuk memperpanjang masa pemberlakuan pembatasan kegiatan masyarakat level 3 dan 4 sampai tanggal 16 Agustus 2021 (Yusuf, 2021).

Kegiatan ini terus dipantau oleh pemerintah guna menekan penularan yang semakin menaik. Pembatasan mobilitas masyarakat merupakan salah satu upaya yang baik dilakukan oleh pemerintah untuk menekan laju penularan. Oleh karena itu memberlakukan pembatasan mobilitas masyarakat tetap harus dilakukan (Delvira Hutabarat, 2021). Setelah berakhir masa pemberlakuan kegiatan ini berdasarkan catatan dari CNBC Indonesia menetapkan bahwa jumlah kasus postif corona per 15 Agustsu 2021 adalah 3.854.354 orang yang artinya bertambah 20.813 orang dari hari sebelumnya, yang artinya kurva kasus postifi Indonesia sedah turun atau melandai yang tidak lagi bergerak ke atas seperti bulan-bulan lalu (CNBC Indonesia, 2021). Dalam kasus ini pemerintah dapat menekan kasus penularan covid-19. Tetapi dampak ini juga dirasakan oleh Gereja yang berada di Desa karena mereka harus online dalam mempersipakan pelayanan kepada para jemaat.

Persatuan Gereja Indonesia atau PGI pun sudah mengimbau kepada seluruh Gereja di Indonesia untuk mengadakan pelayanan dan ibadah secara virtual (CNN Indonesia, 2021). Ini dilakukan untuk menekan angka penyebaran kasus covid-19 yang tengah melonjak di Indonesia. Ini merupakan sebuah keputusan yang baik untuk menekan angka kasus penularan covid-19 yang terjadi di bangsa Indonesia. Semua 
gereja selama selama kebijakan ini masih berlaku dapat mengadakan ibadah virtual online baik lewat zoom ataupun youtube, dan sebagaimnya (Benyamin et al., 2021).

Ini menjadi dampak yang signifikan bagi gereja-gereja yang terletak diwilayah desa untuk menyesuaikan kegiatan beribadah meskipun dengan sarana dan prasaran yang seadainya. Banyak Gerejagereja di wilayah ini melakukan ibadah online masing-masing $\mathrm{di}$ rumah masing-masing bersama sanak keluarga (Marbun, 2104).

\section{Dampak pandemi covid-19 bagi kaum muda Kristen}

Dampak pandemi covid-19 tentunya dialami oleh para pemuda Kristen dalam gereja. Ketika awal mula terjadi pandemi covid-19 kegiatan beribadah kepemudaan masih dapat berjalan dengan baik dilakukan dalam gereja dengan mematuhi protokol Kesehatan yang dicanangkan oleh pemerintah. Para pemuda Kristen antusias dalam mengikuti peribadatan ke gereja, namun ketika terjadi adanya PPKM membuat banyak gereja yang meliburkan kegiatan-kegiatan kepemudaan yang ada di Gereja.
Bahkan tidak semua Gereja dalam melayani pemuda maupun pengurus pemuda yang aktif dalam kegiatan peribadatan online yang diadakan oleh gereja. Banyak yang mengangap bahwa kegiatan kepemudaan saat online saat ini tidak ada rasa yang signifikan terasa ketika mereka ibadah tatap muka. Biasanya mereka dalam kegiatan peribadatan kepemudaan melakukan dengan mengirimkan renungan ke dalam group Whatsapp, virtual zoom, dan video call whatsapp. Dampak langsung yang dirasakan akibat pandemi covid-19 dan kebijakankebijakan yang dilakukan oleh pemerintah ini sangat terasa dalam kegiatan peribadatan untuk gerejagereja yang terbatas akan sarana dan prasarana.

Menurunnya kehadiran dalam ibadah online menunjukkan bahwa pemuda Kristen masih kurang untuk beradaptasi (Adri O. E. Matinahoruw, 2020). Masih banyak yang hanya ikut-ikutan tanpa mengerti apa yang harus dilakukan. Para pengurus kepemudaan pun tidak sigap dalam menghadapi kondisi saat ini karena terbukti dengan tidak melakukan apaapa untuk menunjang pelayanan kepemudaan yang ada. Banyak 
pengurus kepemudaan yang hanya diam-diam saja karena tidak tahu yang harus dilakukan untuk kegiatan kepemudaan. Terbatas waktu dan kondisi yang ada membuat banyak kaum muda Kristen yang ada membuat acara sendiri ketika waktunya mereka harus beribadah.

Dampak ini yang harus diperhatikan dengan sungguhsungguh dari pihak gereja maupun para penggurus kepemudaan yang ada di Gereja. Karena apabila tindakan ini menjadi sebuah kebiasaan yang terjadi di tengah anak muda maka ini akan menjadi hal yang akan sulit untuk dirubah apalagi terjadi untuk anak muda Kristen. Banyak gereja harus bekerja keras dalam menghadapi persoalan yang sedang terjadi dan kondisi ini untuk kebaikan anak muda Kristen yang berada di gereja.

Gereja sedang dibawa kepada dimensi baru untuk menjadi umat yang lebih bijak dalam menyikapi situasi dan kondisi saat ini pandemi covid-19. Setiap peraturan protokol Kesehatan harus dipatuhi dan dijalankan dengan baik. Jangan mudah termakan oleh hoaks yang sedang gempar-gempar yang ramai di media sosial maupun yang semakin beredar di tengah masyarakat. Karena ini hanya meresahkan kehidupan masyarakat apalagi ketika anak muda mudah percaya dengan hoaks ini mereka yang mempunyai emosi yang belum stabil akan mudah terpengaruh dengan kondisi yang salah saat menerima berita yang tidak benar.

Setiap pemuda Kristen sebaiknya harus memiliki dasar terlebih dahulu untuk dapat bertahan disituasi saat ini. Dasar yang dipakai adalah Firman Tuhan, yang dapat menuntun setiap pemuda Kristen agar dapat berjalan dengan baik dalam setiap kehidupan yang ada. Dasar ini harus selalu diperbaharui dengan membaca dan merenungkan Firman Tuhan setiap hari (Ambesa, 2018). Tantangan penurunan partisipasi pemuda Kristen mungkin dapat diatasi gereja-gereja yang di kota besar yang memiliki sarana dan prasaran yang lengkap dalam menunjang kegiatan peribadatan pemuda maupun beribadahan umum. Meskipun penulis juga menemui bahwa terdapat juga gereja di wilayah perkotaan yang terdampak dengan adanya pandemi saat ini yaitu gerejagereja yang tidak dapat beradaptasi 
dengan baik (Lubis et al., 2020). Gereja yang terletak di di desa tentunya lebih memiliki banyak tantangan yang harus untuk dipikirkan dan diatasi dengan baik. Tantangan yang lebih sulit karena terbatasnya sarana dan prasarana yang ada dan juga sumber daya manusia (SDM) yang masih kurang mumpuni. Bukan hanya itu, keberagaman sifat anak muda dengan kesibukan dan kegiatan yang mereka miliki juga mempertambah catatat panjang dari masalah pandemi ini.

Peluang yang sangat menarik dari kondisi saat ini yaitu menambah pengalaman dalam melayani secara luas dengan adanya ibadah online dapat menjangkau banyak jiwa-jiwa yang dapat mendengarkan akan kebenaran firman Tuhan dan bukan hanya untuk kalangan sendiri tetapi untuk kalangan umum. Karena itu, pemuda Kristen harus dapat memberi contoh yang baik terhadap orang lain dengan adanya kondisi saat ini dengan melakukan dan mencontohkan kehidupan yang saling memanusiakan antar sesama manusia (G. K. R. Pakpahan et al., 2021).

Orang Kristen harus dapat menunjukan peran mereka di tengahtengah masyarakat tempat tinggal mereka maupun masyarakat luas yang terdampak pandemi (Bakti, 2020). Dengan adanya kasih yang diberikan kepada masyarakat yang terkena pandemi membuat contoh yang baik yang dapat dilakukan oleh pemuda Kristen. Ini merupakan wujud dari simpati dan kasih kepada sesame manusia yang dapat diterapkan sesuai dengan firman Tuhan. Ada juga peluang juga untuk melatih pengalaman pelayanan di tengah pandemi saat ini. Ketika peluang ini dilakukan dengan baik pasti dapat akan menambah kekuatan kebersamaan dan nilai-nilai Kristus dapat diterapkan dengan baik dalam lingkungan keseharian.

\section{Pemuda Kristen Menghadapi kondisi Pandemi Covid-19}

Pemuda Kristen merupakan pemuda yang dalam kehidupannya harus dapat mencerminkan apa yang Yesus Kristus teladankan (Adri O. E. Matinahoruw, 2020a). Fakta ini mengharuskan pemuda Kristen dapat menempatkan posisi dengan bijak dalam kehidupan sehari-harinya di masyarakat. Apa yang diteladankan oleh Yesus Kristus harus dapat disaksikan dalam kehidupan pemuda Kristen saat ini. Apalagi saat terjadi 
pandemi covid-19 ini harusnya pemuda Kristen mencerminkan teladan yang baik sesuai dengan firman Tuhan yang diajarkan kepada mereka (Christi, 2012).

Ketika para pemuda dapat menjadi teladan yang baik sesuai dengan Firman Tuhan dalam keadaan apapun terjadi pandemi maupun tidak terjadi pandemi mereka akan kuat dalam setiap persoalan-persoalan yang ada. Meskipun ada pandemi covid-19 ini mereka tetap akan beradaptasi dengan baik dengan kondisi yang ada. Pemuda Kristen akan menjadi pelopor terwujudnya pemuda Kristen yang mempuyai integritas baik dan berbudi.

Dalam segi spritualitas remaja pun akan dapat berkembang dengan baik jika para pemuda dapat menerapkan teladan Yesus Kristus dalam kehidupan sehari-hari (Betakore, 2021). Spritualitas remaja merupakan suatu hubungan rohani yang dibangun dan dibentuk dalam diri seorang remaja untuk hidup dalam jalan yang benar yang bersumber dari Tuhan Yesus Kristus dalam menentukan dan mengambil keputusan tentang tujuan hidupnya (Polii, 2021). Dalam hal ini tidak hanya dipengaruhi oleh factor internal juga dipengaruhi oleh faktir ekternal. Keluarga, Gereja, lingkungan merupakan factor ekternal yang dapat menunjang pertumbuhan kerohanian para pemuda. Ketika faktor internal dan factor ekternal dapat seimbang dilakukan dengan baik maka pertumbuhan rohani yang baik akan terjadi dilingkungan kepemudaan. Pemuda Kristen yang kuat membuat gereja kuat dan berkembang.

Indonesia sedang dalam perjuangan menghadapi pandemi covid-19. Bukan hanya tentang Pendidikan yang ada di sekolahsekolah tetapi semua aspek Pendidikan baik itu Pendidikan yang ada di keluarga (Pantan \& Benyamin, 2020), pendidikan yang berada di Gereja, dan pendidikan yang ada di masyarakat.

Sebagai pemuda Kristen yang hidup pada zaman ini, tentu akan lebih positif ketika mempuyai semangat yang lebih dibandingkan pemuda-pemuda yang lain untuk menyalurkan teladan sikap dan perbuatan yang patut untuk dicontohkan kepada semua pemuda maupun orang lain. Pemuda Kristen 
harus melatih diri agar tidak tergantung dengan kondisi saat ini tetapi dapat melewati dengan kekuatan bersama Tuhan Yesus Kristus. Setiap kondisi atau keadaan yang sedang berlangsung saat ini tidak menghambat prinsip dan harapan setiap pemuda yang hidup dalam kehidupan saat ini.

Peran pemuda sangat diperlukan dalam menghadapi kondisi saat ini yang melanda bangsa Indonesia (Setyobekti et al., 2021). Gereja pun sangat butuh kontribusi peran penting dari setiap anak muda Kristen yang ada di Gereja. Dalam kehidupan bangsa dan negara Indonesia tentu perang penting pemuda sangatlah dibutuhkan dalam menghadapi kondisi yang melanda bangsa Indoensia (Trisna, 2016).

Peran pemuda itu dalam bangsa dan negara terwujud dalam tindakan dan perilaku sehari-hari yang sesuai dengan norma-norma yang berlaku di masyarakat. Dalam gereja pun peran pemuda sangat penting yaitu dengan kekuatan yang ada di pemuda dapat menjadikan gereja itu semakin kuat dan gereja itu dapat semakin bertumbuh jika pemuda Kristen menjalankan kewajibannya dengan baik.
Mungkin dalam kondisi saat ini banyak hal yang dikeluhkan dalam setiap kehidupan baik yang dirasakan oleh pemuda kristen maupun oleh setiap orang. Kondisi yang sangat diharuskan bagi setiap lapisan masyarakat untuk menghadapi saat ini.

Gereja pun mengalami kondisi yang harus dilewati untuk dapat beradaptasi dengan kondisi yang ada. Sebelum kondisi saat ini datang banyak kegiatan-kegiatan yang menunjang setiap beribadatan atau pun yang menunjang setiap pertumbuhan rohani setiap anak muda Kristen. Tetapi dengan adanya kondisi pandemi covid-19 ini semua kegiatan-kegiatan dibatasi karena untuk menekan kasus penularan infeksi corona bagi semua manusia.

Tentunya ini harus disikapi dengan bijaksana untuk dapat melewati kasus ini dengan baik. Juga harus pihak penggurus kepemudaan maupun penggurus gereja dapat beradaptasi dengan baik demi menunjang pertumbuhan jemaat yang dilayani. Tentu kondisi ini buka hanya terjadi dikalangan kepemudaan saja tetapi di semua kalangan manusia (Christi, 2012). 
Pemuda yang kuat dalam menghadapi kondisi saat ini maka tulang punggung mereka akan kuat menahan setiap beban-beban kehidupan yang ada. Tentunya pemuda yang dapat beradaptasi dengan kondisi saat ini akan menjadi sebuah pemuda yang luar biasa apalagi setiap pemuda tetap bertumbuh kerohanian meskipun dalam kondisi yang sempit ini dalam berkumpul dan dalam pelayanan yang begitu dibatasi oleh dunia ini.

Ketika setiap pemuda menggunakan hatinya dengan benar yaitu bersumber dengan hati Tuhan Yesus kristus maka semua yang dialami atau pun yang akan dialami ini bukan sebuah permasalahan yang begitu besar tetapi ini hanya proses untuk menuju pribadi yang berdampak bagi semua orang dan tentunya berdampak bagi lingkungan gereja.

Biarlah sikap dan perbuatan yang selaras dengan Tuhan menjadi ujung tombak anak muda untuk menjalani setiap persoalan dan kondisi yang begitu rumit seperti kondisi pandemi covid-19 ini.

\section{KESIMPULAN}

Kaum muda Kristen menjadi suatu kunci yang dapat diharapkan mengambil bagian yang benar untuk kemajuan sebuah gereja. Apalagi dalam kondisi saat ini kemungkinan besar jika diadakan ibadah online pun yang harus bersikap lebih yaitu anak muda Kristen dibandingkan dengan para majelis-majelis yang sudah berumur. Karena jika ini tidak diarahkan kearah yang benar disaat kondisi yang tidak memungkinkan maka susah akan berkembang sebuah gereja itu. Sebaiknya para penggurus pemuda Kristen dalam gereja yang di Desa dapat melakukan hal-hal yang dapat memperkuat para pemuda dalam kondisi apapun yang terjadi. Para pemuda kristen dapat menjadi teladan yang baik sesuai dengan kebenaran Firman Tuhan Yesus Kristus.

Pemuda yang mempuyai kekuatan di tengah kondisi saat ini diperlukan gereja untuk menunjang bertumbuhan Gereja dan kerohanian para jemaat. Penulis percaya bahwa setiap anak muda yang mempunyai dasar dan ujung tombak yang benar akan menjadi anak muda yang berintegritas dan akan menjadi contoh-contoh kehidupan yang baik 
untuk setiap anak muda dan bahkan bukan hanya untuk anak muda saja tetapi setiap orang-orang baik itu orang tua, anak-anak, dan sebagaimnya mereka akan mengerti dan belajar bagaimana hidup sesuai dengan Firman Tuhan Yesus Kristus yang dicontohkan terlebih dahulu lewat perbuatan dan sikap para pemuda Kristen yang ada.

Penelitian ini dapat menjadi kontribusi kepada para penggurus pemuda maupun gereja yang saat ini sedang memikirkan hal-hal yang harus dilakukan di tengah kondisi saat ini. Juga bagi setiap orang yang sedang dalam pergumulan peribadahn kepemudaan maupun persekutuanpersekutuan yang lainnya.

Sekirannya tulisan ini dapat menjadi referensi kepada penelitian yang berhubungan dengan penelitian ini semoga menjadi bermanfaat.

\section{DAFTAR PUSTAKA}

Adri O. E. Matinahoruw. (2020a). PERAN PEMUDA KRISTEN DI TENGAH TANTANGAN REVOLUSI INDUSTRI 4.0 (Analisa Naratif Terhadap Matius 5 : 13 - 16). Jurnal Ilmu Sosial Keagamaan, Vol.1
No.1(1), 53.

Adri O. E. Matinahoruw. (2020b). Peran Pemuda Kristen di Tengah Tantangan Revolusi Industri 4.0 (Analisa Naratif Terhadap Matius 5:13-16). Noumena: Jurnal Ilmu Sosial Keagamaan, 1(1), 53-68.

Ambesa, S. (2018). Tuturan Naratif Berdasarkan Kisah Para Rasul Jilid 2 (Renungan Pagi Wisata Rohani). BPK Gunung Mulia.

Bakti, A. (2020). Peran Penting Kristen Dalam Masa Pandemic. Benyamin, P. I., Sinaga, U. P., \& Gracia, F. Y. (2021). Penggunaan "Platform" Digital pada Pembelajaran Pendidikan Agama Kristen di Era Disrupsi. REGULA FIDEI: Jurnal Pendidikan Agama Kristen, 6(1), 60-68.

Betakore, Y. (2021). Menggapai Pengetahuan , Memperoleh Spiritualitas: Urgensi DwiKonsep PengetahuanSpiritualitas dalam Pendidikan Agama Kristen. Edukatif: Jurnal Ilmu Pendidikan, 3(6), 3975-3983.

Chandra, D. C. (2019). FUNGSI TEORI DALAM METODE PENELITIAN KUALITATIF. 
Reseach Gate.

Christi, A. M. (2012). Pengudusan

Orang Percaya. In Pemikiran

Teolog Gereja Bethel Indonesia

tentang Teologi Pentakosta (pp.

151-171). STT Bethel

Indonesia.

CNBC Indonesia. (2021). PPKM

Level 4 Jawa-Bali Berakhir Hari

Ini, Perlu Diperpanjang?

Redaksi CNBC Indonesia.

CNN Indonesia. (2021). PGI Minta

Gereja Gelar Ibadah Virtual

Selama PPKM Darurat. CNN

Indonesia.

Delvira Hutabarat. (2021). DPR

Minta Pemerintah Perhatikan

Data Sebelum Perpanjang

PPKM. Liputan6.Com.

Kasali, R. (2017). Disruption: Tak

Ada Yang Tidak Bisa Diubah

Motivasi Saja Tidak Cukup.

Kompas Gramedia.

Kumowal, R. L., \& Kalintabu, H.

(2021). Pendidikan Agama

Kristen Gereja Dalam

Menghadapi Kondisi Psikologi

Jemaat Akibat Pandemi Covid-

19. Jurnal Shanan, 5(1), 43-60.

https://doi.org/10.33541/shanan.

v5i1.2581

Lubis, M. R., Ismail, Marpuah,
Rabitha, D., Malihah, F., Adnan, N., Sahrani, \& Abdaloh, D. (2020). Dinamika Aktivitas Keagamaan di Masa Pandemi. LITBANGDIKLAT PRESS.

Marbun, P. _. (2104). Gereja Sebagai Pusat Pendidikan Jemaat. In F. Pantan \& J. Gultom (Eds.), Readdirming out Identity: Isuisu terpilih menjawab perubahan sekaliguas mempertahankan Identitas. Bethel Press.

Pailang, H. S., \& Palar, I. B. (2012).

Membangun Spritual Remaja Masa Kini Berdasarkan Amsal 22:6. Jurnal Jaffray, 10(1), 5986.

Pakpahan, G. (2020). Kecemasan Mahasiswa STT Bethel Indonesia terhadap Covid-19. Jurnal Pendidikan Agama Kristen, 3(1), 20-33.

Pakpahan, G. K. R. (2020). Analysis of Worring among Lecturers of Indonesian Bethel Theology on Covid-19. Medico-Legal

Update, 20(4), 1330-1337. https://doi.org/10.37506/mlu.v2 0i4.2014

Pakpahan, G. K. R., Pantan, F., \& Handojo, E. D. (2021). Menuju 
Gereja Apostolik Transformatif. EPIGRAPHE: Jurnal Teologi Dan Pelayanan Kristiani, 5(1), 136-146.

Panjaitan, Y. C., Edu, F., \& Sumual, I. S. (2021). PENERAPAN METODE PEMBELAJARAN PAAIKES UNTUK

MENINGKATKAN

ANTUSIASME ANAK

SEKOLAH MINGGU DALAM

BERIBADAH ONLINE DI GBI

PAPUA RESTORATION FOR

CHRIST. Jurnal PKM

Setiadharma, 2(2), 83-90.

Pantan, F. (2007). Kompilasi Bahan Ajar Christian Leadership. STT Bethel Indonesia.

Pantan, F., \& Benyamin, P. I. (2020).

Peran Keluarga dalam

Pendidikan Anak pada Masa

Pandemi

Covid-19.

KHARISMATA: Jurnal Teologi

Pantekosta, 3(1), 13-24. https://doi.org/10.47167/kharis. v3i1.43

Polii, M. (2021). Peran Keluarga terhadap Peningkatan Spiritual Remaja pada Masa Pandemi Covid 19. DUNAMIS: Jurnal Teologi Dan Pendidikan Kristiani, $\quad 6(1), \quad 31-45$. https://doi.org/10.30648/dun.v6i
1.386

Setyobekti, A. B., Kathryn, S., \& Sumen, S. (2021). Implementasi Nilai-nilai Bhineka Tunggal Ika dalam Membingkai Keberagaman Pejabat Gereja Bethel Indonesia di DKI Jakarta. SOTIRIA (Jurnal Theologia Dan Pendidikan Agama Kristen), 4(1), 1-10. https://doi.org/10.47166/sot.v4i 1.29

Sugiyono. (2016). Metode Penelitian Kombinasi (Mixed Methods) (Sutopo (ed.); Cetakan 8). Alfabeta.

Suratman, E. (2021). Tinjauan Teologis Terhadap Pandemi Coronavirus Desease 2019 Dalam Prinsip Pembalasan. Manna Rafflesia, 7(2), 258-278. https://doi.org/10.38091/man_ra f.v7i2.145

Susiwijono Moegiarso. (2021). Penerapan PPKM untuk Mengendalikan Laju Covid-19 dan Menjaga Kehidupan Masyarakat. Www.Ekon.Go.Id. Trisna, R. P. (2016). Peranan Orang Kristen dalam Kehidupan Bernegara. In Bergereja dalam Bingkai Kebangsaan. STT Bethel Indonesia. 
Untung, N., Tanonggi, R. O., \& Pekuwali, J. R. (2021). Komsel Pemuridan Kreatif Pemuda GBI Bukit Sion. Jurnal PKM Setiadharma, 1(1), 91-99.

Yusuf. (2021). PPKM Jawa-Bali Diperpanjang hingga 16 Agustus 2021. Kominfo. 